\title{
Ownership concentration, Foreign shareholding, Audit quality and Stock Price Synchronicity: A Critical Review of literature and Evidence from BORSA Istanbul
}

\author{
Prof. Dr. Hatice Düzakın (Çukurova University, Turkey) \\ Ph.D. Candidate Heba Isleem (Çukurova University, Turkey)
}

\begin{abstract}
Stock price synchronicity is used to explain the co-movement of stock price in the same direction over a certain period with the market price. The aim of this seminar paper is critically review literatures which investigated the association between firm specific information such as ownership concentration, foreign shareholding, audit quality and stock price synchronicity. Most of research used to measure stock price synchronicity either classical synchronicity measure, R-square measure or zero return measure. Studies show that stock price synchronicity high in emerging markets comparing to developed markets. Poland, China, Taiwan, Malaysia, Turkey, Columbia and Mexico are among the highest synchronized countries and the reason to their higher synchronicity is poor property right controlling. Ownership concentration, foreign shareholding, audit quality are among the main factors which affected stock price synchronicity. Most of research on this topic are conducted in case of China stock markets due to china is the second higher synchronized country. The finding of reviewed literature indicated that there are negative relationships between ownership concentration, foreign shareholding, audit quality and stock price synchronicity, meaning that low ownership concentration, low foreign ownership and low audit quality resulted in high stock price synchronicity and vice versa. The paper also empirically investigated the association between stock price synchronicity and corporate governance factors such as ownership concentration, foreign shareholding and Percentage of independent directors in the board for 15 companies listed in Borsa Istanbul 30 indexe (BIST 30) covering the period between 2016 and 2019. The finding indicated that only leverage positively associated with stock price synchronicity and foreign ownership, ownership concentration and market to book ratio are negatively associated with stock price synchronicity.
\end{abstract}

\section{Introduction}

\subsection{Statement of the Problem}

Stock price synchronicity is used to explain the movement of stock market price in the uniform direction over a certain period of time together with the market price. Khandaker (2014) defined stock price synchronicity as "the tendency of share market prices to move in the same direction over a particular period of time". Zou, Wilson \& Jia (2017) also defined stock price synchronicity as "the relationship between the change in a single company's stock price and the average market change or moving together". In addition, Pan \& Zhu (2014) described stock return synchronicity as "measures to what extent the individual stock returns would commove with market returns".

Financial economic researchers made an attempt to identify whether a single stock price move together with market, industry or individual firm-specific information. King (1966) shows that the movement of individual stock price described by market and industry information. However, Roll (1988) demonstrated that stock price movements are not mainly explained by market and industry characteristics, instead significantly it explained by firm specific information. Following the finding by Roll (1988), stock price synchronicity has become an important research area in financial. Accordingly, it is important to summarize and investigate empirical studies regarding stock price synchronicity and factors which affect stock price synchronicity.

\subsection{Objectives of the Study}

Subsequent to Roll's insight, several research conducted to identify firm specific factors which affect stock price synchronicity. This paper aims to review the existing literature those explained the relationship between stock price synchronicity and corporate governance factors such as ownership concentration, foreign shareholding and audit quality. It also investigated empirically the association between stock price synchronicity and corporate governance factors such as ownership concentration, foreign shareholding and Percentage of independent directors in the board for 15 companies listed in Borsa Istanbul 30 index (BIST 30).

\subsection{Definitions}

The purpose of this seminar paper is to examine literatures which investigated the association between stock price synchronicity and corporate governance factors such as ownership concentration, foreign shareholding and audit quality. The definition of these three factors is presented as follows.

Ownership concentration: It is one a significant firm specific factor that affects stock price synchronicity. Financial Times defined ownership concentration as "the amount of stock owned by individual investors and large 
blocked shareholders". Gul et al. (2010) measured ownership concentration as a percentage of stocks held by the largest shareholder at the beginning of fiscal year.

Foreign Shareholding: It is another firm specific factor that that affect share price movement. Foreign shareholding is used to explain the amount of share taken by foreign investors. Tas\& Tan (2016) used foreign ownership ratio to investigate the relationship between stock price synchronicity and Foreign Shareholding.

Audit quality: Audit quality can be defined as the combined possibility of identifying and informing financial statement faults (DeAngelo, 1981). The effectiveness of companies' audit report varies whether they are audited by internal or external auditors. Further, Gul et al. (2010) stated that the success of audit report also varies depending on the quality of external auditors. Researchers like Gul et al. (2010) and Zou et al. (2017) used audit quality as a variable that affect stock price synchronicity. They develop a dummy variable whether companies audited by international Big4 auditors or domestic non-Big 4 auditors.

\section{Theoretical Explanation}

Different methods are developed by researchers to measure stock price synchronicity. There are three main methods proposed by researcher to measure stock price synchronicity such as classical synchronicity measure, Rsquare measure and zero return measure (Khandaker, 2014).

\subsection{Classical Synchronicity Measure}

The first measures of stock price synchronicity that applied by both Roll (1988) and Morck et al (2000) is called the classical synchronicity measure. It concerns on parallel movements of stock price through the market. The classical stock price synchronicity measures calculate synchronicity as follows:

$$
P_{x t}=\frac{\operatorname{Max}\left[n_{x t}^{u p}, n_{x t}^{\text {down }}\right]}{n_{x t}^{u p}+n_{x t}^{\text {down }}}
$$

Where, $P_{x t}$ is the net change in price (whether up or down) of the stock of country $x$ in week $t, n_{x t}^{u p}$ is the number of stocks in country $x$ where prices rise in week $t$ and $n_{x t}^{\text {down }}$ is the number of stocks where prices fall. This measure has a highest result of 1.0 for stock markets where the stock prices are exactly synchronized and a lowest result of 0.5 where there are equal numbers of stocks increases and decreases over the period, resemble a market where stocks are not synchronized (Khandaker, 2014). Research like Morck, Yeung and $\mathrm{Yu}(2000)$ and Khandaker and Heaney (2008) are applied this classical synchronicity measure to calculate the synchronicity level.

\subsection{R-square Synchronicity Measure}

The second and commonly applied measure of stock price synchronicity is called R square Measure (Morck et al.2000, Khandaker and Heaney 2000; Skaife et al. 2006). Morck et al.2000 develop ananother measure of share price synchronicity through the following linear regression model.

$$
R_{i t}=\alpha_{i}+\beta_{i} R_{m, i t}+\varepsilon_{i, t}
$$

Where: $R_{i t}$ is the firm $\mathrm{i}$ return for period $\mathrm{t}, R_{m, i t}$ is the market returns of firm $\mathrm{i}$ for $\mathrm{t}$ period, $\varepsilon_{i, t}$ is the error term and $\alpha 1$ and $\beta i$ are estimated parameters. $R^{2}$ Is the percentage of changes in weekly return of stock $i$ in country $j$ explained by variations in country $j$ 's market return. However, the $R^{2}$ measure also explained as follows:

$$
R_{i t}^{2}=\left(\frac{\operatorname{Cov}\left(R_{i} R_{m}\right)}{\sigma_{i} \sigma_{m}}\right)^{2}
$$

Where $\operatorname{Cov}\left(R_{i} R_{m}\right)$ the covariance between the stocks is returns and market returns, $\sigma_{i}$ is the standard deviation of stock $\mathrm{i}$ and $\sigma_{m}$ is the standard deviation of market (Khandaker, 2014). Synchronicity for company $\mathrm{j}$ in each sample year is expressed as:

$$
\text { Synchronicity }_{j}=\log \left(\frac{R_{j}^{2}}{1-R_{j}^{2}}\right)
$$

The reason to use $\log$ conversion $R^{2}$ is to generate a continuous value that limited between 0 and 1 . "High value of Synchronicity shows that a single firm' stock returns co-move closely with the market and/or industry returns, and thus the firm-specific return variation is low" (Kim\&Shi, 2012).

The $R^{2}$ measure is mostly applied by researchers to measure stock price synchronicity. Roll (1988), Skaife et al (2006), Du et al. (2007), Gul et al. (2010), Farooq \& Ahmed (2014), Tas \& Tan (2016), Zou, Wilson \&Jia (2017), He et al. (2018), Hu \&Ma (2019) applied $R^{2}$ measure to calculate stock price synchronicity. 


\subsection{Zero Return Synchronicity Measure}

Zero return measure the comparatively latest model used to measure stock price synchronicity developed by Skaife et al. (2006). They defined this model as "the number of zero return trading days over the fiscal year divided by the total trading days of the firms' fiscal year, where zero return days are days in which the price of the stock does not change compared to the price of the previous days". This finding indicated that zero return measure is a superior measure of synchronicity when a substantial amount of information held into the stock market (Skaife et al., 2006).

The number of zero-return days is measured by computing the number of zero-return trading days over a fiscal year divided by the total number of trading days in that fiscal year. A zero-return day is a day on which the price of a specific share does not change. The zero-return measure is computed as follows:

$$
\text { NOZRD }=\frac{\text { Number of Zero Return Days }}{\text { Total Trading Days in the Year }} \times 100
$$

Where: NOZRD is number of zero return days. A high zero return days number shows a more synchronicity and a low number of zero return days shows a less synchronicity (Khandaker, 2014). Skaife et al. (2006) and Khandaker (2014) applied zero Return synchronicity measure to calculate stock price synchronicity.

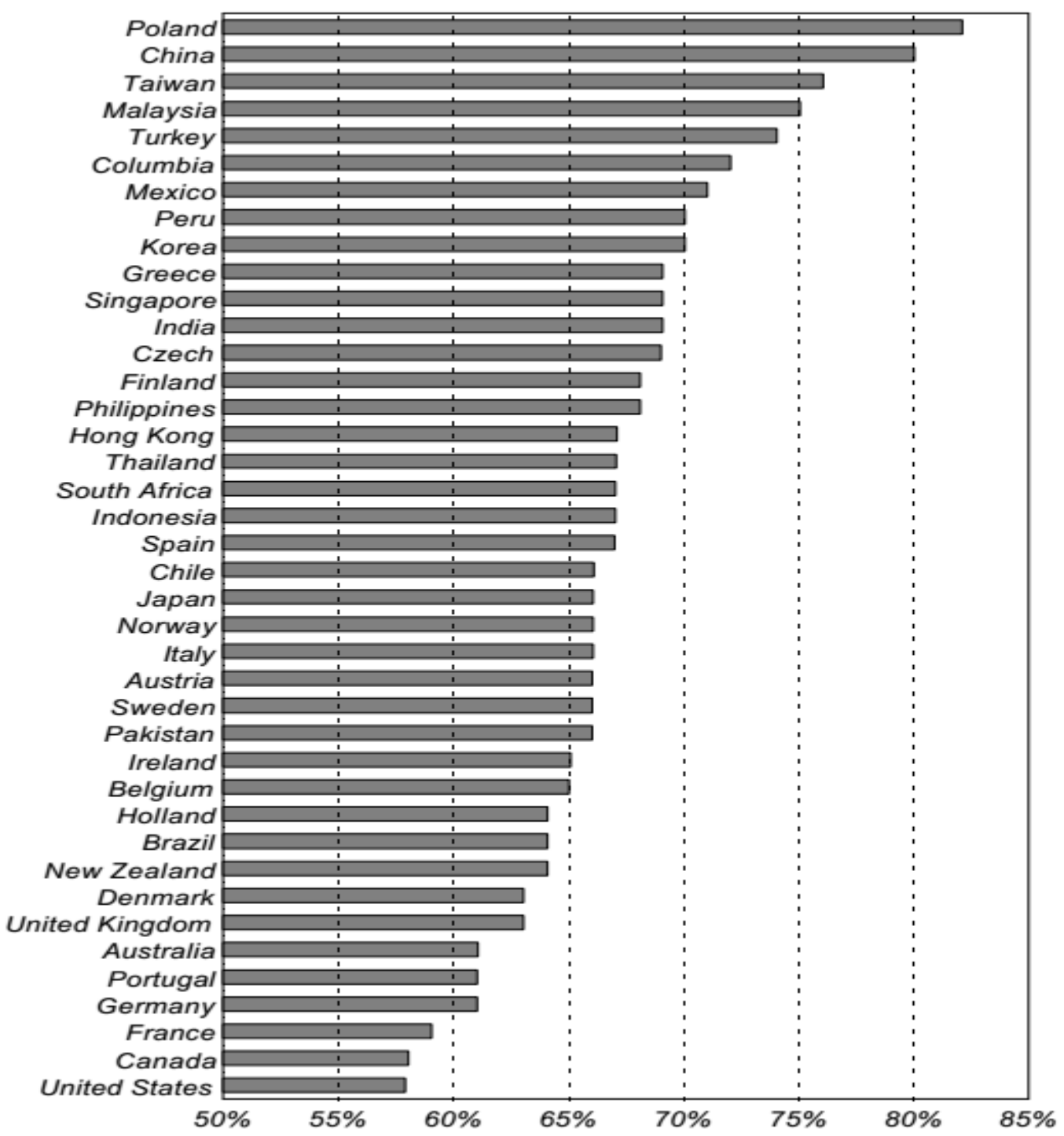

Figure1. Stock price synchronicity around the world. Extract from Morck et al. (2000)

\section{Literature review}

Stock price synchronicity gets a momentum after a study conducted by Roll (1988). He investigated whether market, industry or individual firm-specific information are affected the stock price movement. He used monthly and daily data from both New York and American Stock Exchanges. His finding indicated that the substantial portion of stock price variability was not explained by market information and his result shows the adjusted $R^{2}$ 
was 0.35 and 0.2 for monthly and daily data respectively. He concluded that "This seems to imply the existence of either private information or else occasional frenzy unrelated to concrete information".

Morck et al. (2000) assessed the association between countries economic status and stock price synchronicity. Additionally, they investigate the relationship firm specific information and stock price synchronicity for a total of 15,920 firms across 40 countries. They collected dividend adjusted stock return for all 15920 firms covering the period from 1993 to 1995 . Their finding indicated that stock price synchronicity is more in developing countries that developed economies. They stated that this high stock price synchronicity is not resulted from structural economic characteristics or firm specific information instead; it resulted from poor property right protection in emerging countries. Morck et al. (2000) listed the synchronicity level of countries with percentage of synchronicity. Their result is presented in the following figure.

According to Morck et al. (2000) and as presented in Figure 1, Poland, China, Taiwan, Malaysia, Turkey, Columbia and Mexico are among the highest synchronized countries with more than $70 \%$ of stock price synchronicity.

Skaife et al (2006) publish a study entitled "Does Stock Price Synchronicity Represent Firm-Specific Information? The International Evidence". They investigated the rationality of information-based explanation of stock price co-movement in international markets. Their finding indicated that stock price synchronicity variations through international markets are not resulted from divergences in firm specific information. On the other hand, Choi et al. (2019) stated that stock price synchronicity significantly affected by firm-specific information rather than market/industry-level information. Lin et al. (2015) conducted a study to answer for the question why does China's stock market have highly synchronous stock price movements? Their finding indicated that low-quality government with weak property rights protection is associated with high level of stock price synchronicity in China.

\subsection{Ownership concentration, foreign shareholding, audit quality, and stock price synchronicity: Empirical evidence in Global context}

In this section, empirical studies which investigate the association between Ownership concentration, foreign shareholding, audit quality, and stock price synchronicity are summarized as follows.

Du et al. (2007) conducted a study to identify factors affecting stock price synchronicity in Shanghai and Shenzhen Stock Exchanges. They analyze the effects of nine variables of dynamic corporate governance such as changes in the chairman or general manager, normal change of manager, abnormal change of manager, due to internal sources manager leaves, due to external sources manager leaves, successor takes the position temporarily, successor takes the position permanently, chairman and the general manager are the same and the chainman and the general manager are not the same person and five variables of regional governance such as the relationship between the government and the market, the state of the development of the non-state sector, the growth of a goods market, the growth of factor markets and the legal environment for a market on the stock return synchronicity. The sample includes all listed companies on the stock exchanges of both Shanghai and Shenzhen between 1999 and 2002. Their finding shows that variables such as quality of static corporate governance, dynamic corporate governance mechanisms and quality of regional governance are negative associated with stock return synchronicity. Further, their finding indicated that ownership concentration also negatively correlated with stock price synchronicity.

Gul et al. (2010) examines the impact of ownership concentration, foreign ownership and audit quality on stock price synchronicity for sample of 6,120 firm-year observations and for 1,142 firms over the eight-year period for Chinese listed firms over the 1996-2003. The result indicated that there was a nonlinear relationship between ownership concentration and stock price synchronicity. Further, the result shows that foreign shareholding and audit quality also negatively related with stock price synchronicity, meaning that issuing shares for foreign investors and appointments of high-quality auditors lead to law stock price synchronicity.

Farooq \& Ahmed (2014) investigated the relationship between stock price synchronicity and corporate governance mechanisms such as ownership concentration, and operational complexity in India. Their study covers the period between 2006 and 2008. The finding show that there is a negative correlation between ownership concentration and stock price synchronicity: Firms with lower ownership concentration are associated with higher stock price synchronicity.

Bino et al. (2016) examines the relationship between large shareholder's identity and stock price synchronicity in Middle East and North African (MRNA) countries. Their finding indicted that the stock prices of firms controlled by family or government are less synchronies than firms held by wildly stockholders.

Zou, Wilson \&Jia (2017) investigated the impact of firm specific information such as the impact of foreign ownership, institutional ownership, the concentration of large shareholders, and audit quality on stock price synchronicity for Chinese 16,826 listed firms for the period from 2004 to 2014. The finding indicated that there is a positive association between ownership concentration and price synchronicity. Firms issued shares for both foreign and domestic ownership is negatively correlated with price synchronicity. They also find that firms with 
higher ownership concentration, state ownership, using Big 4 as auditing firms and firms issued H shares in Hong Kong, appear to have relative higher price synchronicity.

Khattak (2017) did his PhD dissertation on the topic ownership structure and stock price synchronicity in Brazil and Russia. He investigated the association between ownership structure and stock price synchronicity using a sample of 121 companies listed in Brazilian stock exchange and 117 companies listed in Moscow stock exchange. The finding indicted that ownership concentration positively associated with stock price synchronicity for both Brazil and Russia.

He et al. (2018) assessed the association between foreign institutional investors and stock price synchronicity for 7566 firm year observations of Chinese stock market for the years 2003 - 2008. The finding indicated that there was a positive relationship between the participation of foreign institutional and stock price synchronicity. Furthermore, audit quality was correlated with stock price synchronicity negatively.

Hu \&Ma (2019) examined the effect of ownership concentration, foreign shareholding and audit quality on the stock price synchronicity of listed companies in China through the period from 2009 to 2018. The result indicted that first; there are a concave function relationship between ownership concentration and stock price synchronicity: as the concentration of equity increases, the stock price synchronization gradually decreases to a certain threshold. Second, foreign shareholding is negatively associated with stock price synchronicity. Third, when the companies audit quality increase, the stock price synchronization is decrease.

\subsection{Ownership concentration, foreign shareholding, audit quality, and stock price synchronicity: Empirical evidence in Turkey}

This section depicted to review empirical evidence which assed Ownership concentration, foreign shareholding, audit quality, and stock price synchronicity in case of Turkey. Unfortunately, the author can find only one study regarding this topic.

Tas \& Tan (2016) assessed the impact of corporate governance and foreign ownership on stock price synchronicity in Turkey. They collected daily returns for 86 firms listed in Borsa Istanbul 100 index covering the period from 2009-2014. They calculated stock price synchronicity depending on studies such as Morck et al. (2000) and Gul et al. (2010) and analyzed with selected variables. Their finding indicated that foreign ownership and board independence are negatively associated with stock price synchronicity. Therefore, the higher share of foreign ownership and more independent directors in board are resulted in low stock price synchronicity.

\section{Data and Methodologies}

\subsection{Data}

This seminar paper covers 15 listed firms in Borsa Istanbul 30 Index (BIST30) between the periods from 2016 to 2019. Initially 16 firms were selected by excluding financial sector firms and holdings. Finally, 15 firms were investigated by excluding one firm because of lack of enough data. The firms are involved in BIST30 Index as of 11.05.2020. The weekly adjusted stock prices for BIST 30 index and 15 sample firms are collected from www.m.investing.com. Selected sample companies are presented in Table 1 below. The data for independent and control variables are collected from the annual reports of the specified years available in the websites of the selected companies.

\begin{tabular}{|l|l|l|}
\hline No. & Company Name & Symbol \\
\hline 1 & Arçelik A.Ş. & ARCLK \\
\hline 2 & Aselsan Elektronik Sanayi Ve Ticaret A.Ş. & ASELS \\
\hline 3 & BİM Birleşik Mağazalar A.Ş. & BIMAS \\
\hline 4 & EREĞLİ Demir Ve Çelik Fabrikalari T.A.Ş & EREGL \\
\hline 5 & Koza Altin İşletmeleri A.Ş. & KOZAL \\
\hline 6 & Koza Anadolu Metal Madencilik İşletmeleri A.Ş. & KOZAA \\
\hline 7 & Pegasus Hava Taşimaciliği A.Ş. & PGSUS \\
\hline 8 & Soda Sanayii A.Ş & SODA \\
\hline 9 & Tofaş Türk Otomobil Fabrikasi A.Ş. & TOASO \\
\hline 10 & Trakya Cam Sanayii A.Ş. & TRKCM \\
\hline 11 & Turkcell İletişim Hizmetleri A.Ş. & TCELL \\
\hline 12 & Tüpraş-Türkiye Petrol Rafinerileri A.Ş. & TUPRS \\
\hline 13 & Türk Hava Yollari A.O. & THYAO \\
\hline 14 & Türkiye Şişe Ve Cam Fabrikalari A.Ş. & SISE \\
\hline 15 & Türk Telekomünikasyon A.Ş & TTKOM \\
\hline
\end{tabular}

Table1: Selected sample companies and their symbols in the stock market 


\subsection{Variables}

To investigate factors affecting stock price synchronicity, the following variables are selected based on studies such as Gul et al. (2010), Tas \& Tan (2016) and Hu \&Ma (2019).

\begin{tabular}{|l|l|}
\hline \multicolumn{2}{|l|}{ Dependent Variable } \\
\hline SYNCH & Stock price synchronicity calculated as log $\left(R^{2} /\left(1-R^{2)}\right)\right.$ \\
\hline Independent Variables \\
\hline LSHR & $\begin{array}{l}\text { Largest shareholders ration (is the percentage of shares held by the largest shareholder at the } \\
\text { beginning of fiscal year). }\end{array}$ \\
\hline FOR & Foreign ownership ratio (percentage of public offered shares owned by foreign investors) \\
\hline PID & $\begin{array}{l}\text { Percentage of independent directors in the board (The percentage of independent or outsider } \\
\text { directors in the board). }\end{array}$ \\
\hline Control Variables \\
\hline FSIZE & Firm size is calculated as the log of total assets at the end of the fiscal year. \\
\hline MB & $\begin{array}{l}\text { Market-to-book ratio, computed as the total market value of equity, divided by the total net } \\
\text { assets at the end of the fiscal year. }\end{array}$ \\
\hline LEV & Leverage computed as total liabilities divided by total assets. \\
\hline ROE & $\begin{array}{l}\text { Return on equity is the profitability of the company calculated as operating profit divided by } \\
\text { shareholders' equity at the end of the fiscal year. }\end{array}$ \\
\hline
\end{tabular}

Table 2: Selected Variables and their Definition

\subsection{Model specification}

After identifying the dependent, independent and control variables, the following regression model is developed and analyzed.

$$
S Y N C H=\beta_{0}+\beta_{1} \text { LSHR }_{i, t}+\beta_{2} F_{O R} R_{i, t}+\beta_{3} P I D_{i, t}+\beta_{3} \text { Contro var }_{i, t}+\varepsilon_{i, t}
$$

\subsection{Stock Price Synchronicity}

As we discussed in the theoretical explanation part of this paper, there are three types of stock price synchronicity measures. To calculate the sample companies price synchronicity, the commonly applied measure i.e. R square measure is applied. The $\mathrm{r}$ square measure is the percentage variation in weekly return of stock in company $x$ explained by market return (Khandaker, 2011). For this paper, BIST 30 index is used representing the market.

$$
R_{X T}^{2}=\frac{\operatorname{COV}\left(R_{i}, R_{m}\right)}{\sigma_{i} \sigma_{m}}
$$

Where: $\operatorname{COV}\left(R_{i}, R_{m}\right)$ is the covariance between is the share return and the market return, $\sigma_{i}$ is the standard deviation of asset $x$ and $\sigma_{m}$ is the standard deviation of the market return. A higher R square indicates a higher stock return synchronicity and vice versa. The four-year average R square for 15 sample countries is displayed in Table 3. It shows that among 15 sample companies ARCLK, ERGEL, PGSUS, TCELL, THYAO and TTKOM have higher $\mathrm{R}$ square, meaning that they are higher synchronous firms.

\begin{tabular}{|l|r|}
\hline Company & $\boldsymbol{R}^{\mathbf{2}}$ \\
\hline ARCLK & 0.3131 \\
\hline ASELS & 0.0539 \\
\hline BIMAS & 0.2984 \\
\hline EREGL & 0.3590 \\
\hline KOZAL & 0.1071 \\
\hline KOZAA & 0.0981 \\
\hline PGSUS & 0.3171 \\
\hline SODA & 0.0554 \\
\hline TOASO & 0.2670 \\
\hline TRKCM & 0.2686 \\
\hline TCELL & 0.4306 \\
\hline TUPRS & 0.2718 \\
\hline THYAO & 0.3853 \\
\hline SISE & 0.3095 \\
\hline TTKOM & 0.4334 \\
\hline
\end{tabular}

Table 3: Average R square 


\section{Empirical results}

\subsection{Descriptive Statistics}

Descriptive statistics displays that the mean $R^{2}$ is 0.2831 . This confirms the study of Morck et al. (2000); they found that Turkey is one of the five highest synchronous countries in their study. Standard deviation of synchronicity is 0.838 that shows the flow of firm-specific information to the market changes across firms in a wide range. Descriptive statistics, table 5 , also displays the mean of foreign ownership ratio is 0.583 . This shows most of public offered shares are taken by foreign investors. The mean of ownership concentration is 0.536 and this shows most of sample firs shares are taken by one specific investor. The mean of independent board members ratio is 0.332 .

\begin{tabular}{|l|l|l|l|l|l|l|l|l|l|}
\hline & \multicolumn{1}{|c|}{$R^{2}$} & SYNCH & FOR & FSIZE & LEV & LSHR & MB & PID & ROE \\
\hline Mean & 0.2831 & -0.622 & 0.583 & 8.388 & 0.521 & 0.536 & 0.799 & 0.332 & 0.275 \\
\hline Median & 0.2579 & -0.459 & 0.585 & 7.592 & 0.586 & 0.523 & 0.683 & 0.330 & 0.232 \\
\hline Maximum & 0.6797 & 0.327 & 0.896 & 11.170 & 0.870 & 0.846 & 2.910 & 0.570 & 0.703 \\
\hline Minimum & 0.0001 & -4.179 & 0.175 & 6.491 & 0.072 & 0.148 & 0.075 & 0.150 & -0.049 \\
\hline Std. Dev. & 0.1747 & 0.838 & 0.202 & 1.545 & 0.242 & 0.147 & 0.586 & 0.077 & 0.169 \\
\hline Probability & 0.4169 & 0.000 & 0.292 & 0.025 & 0.051 & 0.005 & 0.000 & 0.004 & 0.010 \\
\hline
\end{tabular}

Table 4: Descriptive Statistics

\section{Regression Result}

To assess the association between stock price synchronicity and corporate governance factors such as ownership concentration, foreign shareholding and Percentage of independent directors in the board, Panel regression applied. Panel data can be regressed pooled regression and fixed or random effect model (Sayed Hossain, 2013).

\subsection{Pooled Regression}

This model analysis the association between dependent and independent variable by complaining all sample companies as the one company. The problem of this model is neglecting the cross-section and time serious nature of the data (Sayed Hossain, 2013). The result of pooled regression is presented in the following table.

\begin{tabular}{crrrr}
\hline \hline Variable & Coefficient & Std. Error & t-Statistic & Prob. \\
\hline \hline C & -0.882637 & 0.926596 & -0.952559 & 0.3452 \\
FOR & -0.468131 & 0.595228 & -0.786473 & 0.4352 \\
FSIZE & 0.090942 & 0.071479 & 1.272291 & 0.2089 \\
LEV & 1.527708 & 0.435022 & 3.511791 & $\mathbf{0 . 0 0 0 9}$ \\
LSHR & -1.600338 & 0.783449 & -2.042684 & $\mathbf{0 . 0 4 6 2}$ \\
MB & -0.264993 & 0.181844 & -1.457254 & 0.1511 \\
PID & 0.829025 & 1.451811 & 0.571028 & 0.5704 \\
ROE & -0.843004 & 0.688748 & -1.223966 & 0.2265 \\
\hline \hline
\end{tabular}

Table 5: Pooled Regression Result

The result of pooled regression shows that only ownership concentration and leverage are significantly associated with stock price synchronicity. Leverage positively and ownership concentration negatively associated with stock price synchronicity.

\subsection{Fixed or Random Effect Model}

To decide whether fixed or random effect model is appropriate for the collected data, Hausman test should applied. The null hypothesis for hausman test is random effect model is appropriate and the alternative hypothesis is the fixed effect model is appropriate. If the P-value is less than 5\%, we can accept the alternative hypothesis and if the P-value is greater than 5\%, we can accept the null hypothesis (Sayed Hossain, 2013). The Hausman test result is presented in the following table.

\begin{tabular}{lrrr}
\hline \hline Test Summary & Chi-Sq. Statistic & Chi-Sq. d.f. & Prob. \\
\hline \hline Cross-section random & 14.496731 & 7 & 0.0430 \\
\hline \hline
\end{tabular}

Table 6: Hausman test result 
The result shows that $\mathrm{P}$ - value is less than 5\% and meaning that fixed effect model is appropriate for these data and the result of fixed effect model is presented as follows.

\begin{tabular}{crrrr}
\hline \hline Variable & Coefficient & Std. Error & t-Statistic & Prob. \\
\hline \hline C & 13.93951 & 6.071403 & 2.295928 & 0.0273 \\
FOR & -2.484565 & 0.908317 & -2.735351 & $\mathbf{0 . 0 0 9 4}$ \\
FSIZE & -0.611272 & 0.493499 & -1.238650 & 0.2231 \\
LEV & 2.363935 & 0.846523 & 2.792522 & $\mathbf{0 . 0 0 8 1}$ \\
LSHR & -13.62481 & 5.997215 & -2.271855 & $\mathbf{0 . 0 2 8 8}$ \\
MB & -1.159569 & 0.458509 & -2.528999 & $\mathbf{0 . 0 1 5 7}$ \\
PID & -2.067611 & 3.380146 & -0.611693 & 0.5444 \\
ROE & -1.111685 & 0.890218 & -1.248778 & 0.2194 \\
\hline \hline
\end{tabular}

Table 7: Fixed Effect Model Regression Result

The fixed effect model result shows that foreign ownership, ownership concentration, leverage and market to book ratio are significantly associated with stock price synchronicity with P-value of 0.0094, 0.0288, 0.0081 and 0.0157 respectively. Only leverage positively associated with stock price synchronicity and foreign ownership, ownership concentration and market to book ratio are negatively associated with stock price synchronicity.

Foreign ownership ratio significantly and negatively $(-2.48)$ correlated with stock price synchronicity. This indicates that higher foreign ownership in the firm ownership structure will decrease stock price synchronicity. Ownership concentration also significantly and negatively (-13.6) associated with stock price synchronicity. This shows that when the shares concentrated in a few shareholders will decrease stock price synchronicity. Market to Book ratio also significantly and negatively $(-1.15)$ correlated with stock price synchronicity. This suggests that higher market to book ratio will decrees synchronicity.

Leverage is the only variable significantly and positively (2.36) correlated with synchronicity. This indicates more leveraged firms will increase synchronicity. The findings of this seminar study coincide with the study of Tas \& Tan (2016).

\section{Summary and Conclusion}

Stock price synchronicity is a method used to describe to what degree the specific stock price would parlay move with market prices. In short, stock price synchronicity used to describe the co-movement of individual stock price with market price. Before Roll's study in 1988, it was expected to only market and industry factors affect stock price variability. However, Roll (1988) showed an insight regarding firm specific information can explains stock price variability.

Different attempted carried out to measure stock price synchronicity using different methods. Classical synchronicity measure, R-square measure or zero returns measure are found to be the main measure of stock price synchronicity. According to (Skaife et al., 2006), zero return measure is a superior measure of synchronicity when a considerable amount of information held into the stock market.

Considering stock price synchronicity is high whether in developed or developing countries, studies shows that stock price synchronicity is high in emerging countries due to different reasons. Morck et al. (2000) stated that high stock price synchronicity is resulted from poor property right control mechanism in countries. Lin et al. (2015) also indicated that low-quality government with weak property rights protection is associated with high level of stock price synchronicity in China. According to Morck et al. (2000) Poland, China, Taiwan, Malaysia, Turkey, Columbia and Mexico are among the highest synchronized countries with more than $70 \%$ of stock price synchronicity.

Firm specific information such as ownership concentration, foreign ownership, institutional, and audit quality are all among the main factors which affect stock price synchronicity. For this purpose, studies conducted on this area are reviewed and their finding indicated that there are negative relationships between ownership concentration, foreign shareholding, audit quality and stock price synchronicity, meaning that low ownership concentration, low foreign ownership and low audit quality resulted in low stock price synchronicity and vice versa.

The empirical find of the paper shows that foreign ownership, ownership concentration, leverage and market to book ratio are significantly associated with stock price synchronicity with P-value of $0.0094,0.0288,0.0081$ and 0.0157 respectively. Only leverage positively associated with stock price synchronicity and foreign ownership, ownership concentration and market to book ratio are negatively associated with stock price synchronicity. 


\section{References}

- Bino,A., Abu-Ghunmi,D., Tayeh,M. \& Shubita,D. (2016). Large Shareholder's Identity and Stock Price Synchronicity: Evidence from a MENA Market. International Journal of Financial Research Vol. 7, No. 1; 2016. doi:10.5430/ijfr.v7n1p135.

- Choi,j., Choi,S., Myers,L. \& Ziebart,D. (2019). Financial Statement Comparability and the Informativeness of Stock Prices About Future Earnings. Contemporary Accounting Research Vol. 36 No. 1 (Spring 2019) pp. 389-417. doi:10.1111/1911-3846.12442.

- DeAngelo, L.E.. 1981. Auditor size and audit quality. Journal of Accounting and Economics 3 (3): $183-199$.

- Du,J. Hao,H,\& Xu,C. (2007). What Determines the Synchronicity of Stock Price Movements in the Shanghai and Shenzhen Stock Exchanges? Shanghai-Hong Kong Development Institute Occasional Paper No. 18.

- Farooq,O. \& Ahmed,S.(2014). Stock price synchronicity and corporate governance mechanisms: evidence from an emerging market. Int. J. Accounting, Auditing and Performance Evaluation, Vol. 10, No. 4, 2014.

- Gul, F.A., Kim, J-B. and Qiu, A.A. (2010) 'Ownership concentration, foreign shareholding, audit quality, and stock price synchronicity: evidence from China', Journal of Financial Economics, Vol. 95, No. 3, pp.425-442.

- He,T., Li,W.\& Tang,G. (2018). Foreign institutional investors and stock price synchronicity of Chinese listed frms: further evidence. Eurasian Economic Review. https://doi.org/10.1007/s40822-018-0122-4

- Hu,X.\& Ma,Y.(2019). The Effect of Equity Concentration, Dual Listing and Audit Quality on Stock Price Synchronicity. Advances in Economics, Business and Management Research, volume 94.

- $\quad$ Khandaker, S., and R. Heaney, 2008, Do emerging markets have higher stock synchronicity? The international evidence. 9th International Business Research Conference, Melbourne, Australia, World Business Institute.

- Khandaker,S. (2011).R square measure of stock synchronicity. International Review of Business Research paper,7(1),165-175.

- Khandaker,S. (2014). Comparison between Stock Synchronicity measures- An Empirical Analysis. A.T. Business Management Review', Vol. 10, Issue 2, pp. 52-65, 2014 (ISSN: 1813-0534.

- Khattak,M. (2017). Ownership Structure and Stock price synchronicity in Brazil and Russia. A PhD Thesis submitted to Auckland University of Technology.

- Kim, J. -B., \& Shi, H. (2012). IFRS reporting, firm-specific information flows, and institutional environments: International evidence. Review of Accounting Studies, 17, 474-517.

- $\quad$ King, B., 1966. Market and industry factors in stock price behavior. Journal of Business 39, 139-190.

- $\quad$ Lin,K.,J., Karim ,K.\&,Carter,C. (2015). Why does China's stock market have highly synchronous stock price movements? An information supply perspective. Advances in Accounting, incorporating Advances in International Accounting xxx (2015) xxx-Xxx.

- Morck, R., Yeung, B., Yu, W., (2000). The information content of stock markets: why do emerging markets have synchronous stock price movements? Journal of Financial Economics 58, 215-260.

- Pan, N. \& Zhu , H. (2014). A Review of Stock Return Synchronicity. International Conference on Economic Management and Social Science (EMSS 2014).

- $\quad$ Roll, R., 1988. R2. Journal of Finance 43, 541-566.

- $\quad$ Sayed Hossain. (2013, September 25).Panel Data.Fixed and Random effect.Model one. EVIEWS. https://youtu.be/MKyR0L1-02k

- $\quad$ Skaife, A. H., J. Gassen, and R. La.Ford, 2006, Does stock price synchronicity represent firm specific information? The international evidence, MIT Sloan Research Paper, 4551-05. http://ssrn.com/abstract=768024.

- Tas1, O. \& Tan, S. (2016).Corporate Governance, Foreign Ownership and Stock Price Synchronicity: Evidence From Borsa Istanbul. Journal of Economics, Finance and Accounting - JEFA (2016), Vol.3 (2). DOI: 10.17261/Pressacademia.2016219778

- Zou1, L., Wilson, W. \& Jia, S. (2017). Do Qualified Foreign Institutional Investors Improve Information Efficiency: A Test Of Stock Price Synchronicity In China? Asian Economic and Financial Review, 2017, 7(5): 456-469. 